Madrygal. Revista de Estudios Gallegos

ISSN: 1138-9664

\title{
Lírica
}

\section{nena de feira}

Tamara Andrés

teño cinco anos e atraveso unha praza que concibo inmensa ateigada de xente que non me repara

as luces de neon golpéanme o corpo e eu inspiro fortemente

o algodón de azucre, as mazás de caramelo, as améndoas garrapiñadas

sei que o señor do dragón me convidará a subir no animal

pero eu estarei soa

gustaríame que papá deixase o posto e sentase ao meu carón

pero eu estarei soa

e malia todo sentarei na cabina

finxirei a excitación da velocidade

a sorpresa dun traxecto pequeneiro e repetitivo

aprenderei así a estar soa

e a envexar

a carón do posto de papá eu poñía o meu postiño

colocaba os colares de cunchas, os resortes,

os chupetes de cristal, os paliños fluorescentes,

os chifres acuáticos que se pensaban paxaros

pero ninguén ollaba o postiño dunha nena

coma ninguén se detén a comprender a infancia

(aprendín axiña que os cartos

sempre van para os grandes) 
a masa simplemente transitaba e dicía que riquiña

e ás veces alguén poñía ollada como de ollar algo entrañable

eu non quería ser riquiña nin entrañable

eu quería vender e dicirlle a papá

mira, papá, estes cartos son teus / non, eu non quero nada / quero que os gardes e busques un traballo que non dobregue o teu corpo / un traballo como os dos outros papás

lembro as napolitanas de chocolate e a tenda de lambetadas da Guarda os cruasáns á prancha da Pobra e as ancas de ra e as crujicroques de Arcade Lalín era territorio de carne e mais de aros rítmicos Padrón, de Rosalía, de fariña azucrada, de cheiro a polbo cocido lembro os ollos dos farois preguiceiros nas idas nos regresos, o corpo magoado combatendo contra o sono os berros do día acalando a pel, luíndo

houbo unha época na que poñiamos dous postos un de camisetas e fulares e outro de cuncas cheas de antropónimos no segundo aprendín que hai nomes comúns que resultan estraños e viceversa que xefa da casa era algo gracioso e que as avoas queren a todos os netos por igual que a cerámica era bo agasallo pros de Alemaña pros de Suiza cóllelle tamén a do Barça a este a do Madrid a aquel xa estarán grandes a ver as tallas

e para as nenas? tes algo bonito?

$*$

os zoqueiros

os polbeiros

os das plantas

os das cintas

na feira todos eran coñecidos polo que vendían

agás os negros

os gitanos 